\title{
Erratum
}

\section{Charles Darwin's use of theology in the Origin of Species - Erratum}

\author{
STEPHEN DILLEY
}

doi:10.1017/S000708741100032X, published by Cambridge University Press, 4 May 2011

It is regretted that the originally published paper contained an error. On page 28 , the third sentence in the first full paragraph should read:

'Positiva theology legitimized everything from the trustworthiness of empirical data, to the famed homology argument, to Darwin's naturalized method.'

We apologise for this oversight.

\section{References}

STEPHEN DILLEY, Charles Darwin's use of theology in the Origin of Species, BJHS (2011), published by Cambridge University Press, 4 May 2011, doi:10.1017/S000708741100032X 